\title{
Trade, Exchange Rate Regimes and Output Co-Movement: Evidence from the Great Depression $^{*}$
}

\author{
August 26, 2010 \\ Gabriel Mathy \\ University of California, Davis \\ Christopher M. Meissner \\ University of California, Davis and NBER
}

\begin{abstract}
:
A large body of cross-country empirical evidence isolates monetary policy and trade integration as key determinants of business cycle co-movement. Consistent with this, the conventional view is that reconstruction of the gold standard and trade linkages allowed for the transmission of the shock of the Depression worldwide in 1929. It is puzzling then to see that as international integration and monetary coordination rose between 1920 and 1929 co-movement first fell and then rose. Fixed exchange rates did not disappear after the Depression, but the unconditional average of bilateral co-movement declined. Much of the fall after 1932 was driven by an interbloc fall in co-movement. Throughout the period, exchange rate regimes and trade were associated with higher co-movement at the bilateral level however.
\end{abstract}

* Gratitude to Paul Bergin, Chris Hanes, Oscar Jordà, John Landon-Lane, Kris James Mitchener, Suresh Naidu, Gary Richardson, Alan M. Taylor, and other seminar and conference participants at the All UC Group in Economic History conference and UC Davis for helpful comments and suggestions. Jan Tore Klovland, David Jacks, Jakob Madsen, and Dennis Novy shared data with us. Errors remain the sole responsibility of the authors. 


\section{Introduction}

It is now widely agreed that monetary and exchange rate policies were central to economic outcomes during the 1930s Great Depression. The gold standard, a global system of fixed exchange rates was the main transmission mechanism for the Great Depression (Eichengreen, 1992a). Nations that broke free from the gold standard in the 1930s recovered more quickly and hence had divergent economic outcomes from those clinging to an increasingly anachronistic metallic regime (Choudhri and Kochin 1980, Eichengreen and Sachs, 1985 and 1986 and Eichengreen, 1992a).

These views challenged an established belief, inherited from policy makers of the interwar period, that devaluation and expansionary monetary policy led to greater uncertainty, beggar-thy-neighbor impacts, and further collapse of the global economy. The gold standard in this view was the proper shelter for an economy. Other policies posed challenges for recovery. Although a conventional view in the 1920s and 1930s was that the gold standard tied nations' fortunes together in prosperity, it was not blamed for bringing the world's economies down together. It was only slowly recognized that political changes had altered the gold standard's functionality as a mechanism of smooth adjustment and that recovery depended upon new and unorthodox expansionary policies (Eichengreen, 1992a).

The new consensus that the gold standard mattered for the international spread of the Great Depression does not however preclude further study into the international transmission of economic shocks during this volatile period. And even if the closely related idea that devaluation mattered for recovery has given way to the notion that the 
gold standard constrained policy options throughout the interwar period, we do not fully understand the factors associated with the transmission of foreign shocks during the Great Depression and the rest of the interwar years. No such study has yet to be undertaken.

There is, however, significant variation in the timing and face of economic recovery in the 1930s in the same way as there are differences in the way nations slid into depression. Empirical explanations for such patterns of "output co-movement" from recent decades focus on both trade flows (Frankel and Rose, 1998) and monetary regimes and fixed exchange rates (Artis and Zheng, 1997 Clark and van Wincoop, 2001) as well as patterns of specialization, industrial structure and common shocks. We investigate these issues during the years surrounding the Great Depression --an important moment of economic change and international crisis.

As a matter of fact, trade and monetary regimes do not obviously explain the data in our sample from the interwar period. Global trade patterns were somewhat stable and international capital flows resumed for many countries between 1920 and 1929. The 1920s also saw nations re-adopt the gold standard. Still, the average degree of comovement did not trend upwards. Instead the data show a U-shaped pattern with the trough coinciding with 1926 and 1927. A puzzle arises again after 1932 when synchronization decreased. This could be rationalized as the outcome of the well-known rise of autarkic policies and exchange rate variability (e.g., Basu and Taylor, 1999). On the other hand, trade links actually came back to life after 1932 and many nations readopted fixed exchange rates. Rather than go completely autarkic, there was a recoordination of monetary policies, and an active effort to revive trade existed albeit in new and smaller blocs and at the bilateral level. This suggests that the explanation for the 
1930s hides in the details of the rearrangement of the trade links and the reference countries for monetary policy.

To further our understanding of co-movement in the inter-war period, we study bilateral co-movement of industrial production conditioning on many key determinants. This approach has significant potential to explain the anomalous behavior of comovement in the inter-war period. Moreover, we provide further evidence regarding the robust determinants of business cycle co-movement on a previously un-exploited data set. One limitation of our reduced form, empirical approach is that it does not shed too much light on transmission of shocks versus co-movement of underlying shocks.

We also contribute, in a peripheral way, to the debate on monetary versus real forces in the Great Depression. A recent addition to the literature on the Great Depression de-emphasizes the role of monetary forces in the Depression but it studies the Depression mainly on a country-by-country basis. The essays in Kehoe and Prescott (2007) are largely concerned with domestic policies and Cole and Ohanian (1999) and Bordo, Choudhri and Erceg (2000) look at the US case in isolation. ${ }^{1}$ This literature has focused on real factors instead of monetary forces as a cause of the depression because of the implied persistent non-neutrality of money. Monetary policies might however determine the transmission of real shocks in the short-run even if they are alleged not to matter in the long run. Since by its nature, the Great Depression was an international phenomenon, it also seems interesting to focus on the international connections between countries including their monetary regimes as well as trade flows.

\footnotetext{
${ }^{1}$ International trade costs play a role in Perri and Quadrini (2002) which was reproduced in the Kehoe and Prescott (2007) edited volume.
} 


\section{Monetary Policy, Integration and Business Cycles in the Interwar Period}

After the Treaty of Versailles was signed in 1919, nations travelled a treacherous road to recovery with their ultimate destiny being the Great Depression. We provide a stylized view of the path of monetary policy and international trade during the interwar period by breaking the years 1920 to 1938 into four phases. Our goal is to briefly survey the issues relevant to the transmission of the international business cycle between 1920 and 1938. For reference, Figure 1 shows the path of industrial output for the ten countries which we analyze.

World War I drastically changed the international supply chain, national balance sheets and price levels. These had risen between 1914 and 1919 just under twofold in the United States, slightly more than twofold in Britain, and ten-fold in France. The destruction of the war created the potential for quick recovery to the pre-war trend amongst all belligerents as nations sprang back to their long-run levels of income per

person, but the ill thought-out financial arrangements for reparations and other problems with the gold exchange standard ultimately generated great instability and potential for the international propagation of domestic shocks.

The first phase of monetary history occurred between roughly 1920 and 1928. During this period most nations attempted to return to the gold standard with various levels of alacrity to their pre-war parity. The United States, never abandoning gold, and Great Britain drove prices down to levels consistent with their pre-war gold parities. By 1925 Britain had re-anchored itself to the gold standard. Elsewhere, political disputes over readjustment led to intense monetary shocks and high- or hyper-inflation. France settled for a return to the gold standard at a depreciated parity (de facto in 1926 and de 
jure in 1928) as did Germany but with a new currency in hand after a bout of hyperinflation. On the periphery, for instance in Scandinavia, nations used a mix of deflationary policies and devaluation to attain monetary stability (Klovland, 1998).

The incipient reconstruction of the international economy with rising or stable trade flows and resurgent capital movements may have also increased the unconditional, raw cross-country co-movement of de-trended industrial output but only after 1927. In 1925 Churchill, as chancellor of the exchequer, exclaimed felicitously that "all the countries related to the gold standard will move together like ships in a harbour whose gangways are joined and who rise and fall together with the tide." (Foreman-Peck, 1995 p. 226).

By 1928 the international gold exchange standard operated to connect many disparate financial systems. For those that argue that the gold standard mattered, the impulse for the Great Depression occurred in 1928 when US Federal Reserve policy became tighter. ${ }^{2}$ American monetary policy pinched less-developed commodity exportbased economies by dampening American demand for their products. Elsewhere, fragile commitments and weak credibility in adherence to the gold standard forced nations to follow the rise in American interest rates with even larger hikes, severely damaging demand (Eichengreen, 1992a). Into 1930, nations attempted to maintain the gold standard, but by the time that Britain had jumped the gold ship in September 1931 it was clear to many (but not all) that the gold standard was a constraint in terms of recovery and a channel for transmission. Churchill's joyous prediction was rendered a ghastly reality.

\footnotetext{
${ }^{2}$ The German economy headed into its downturn in 1927 with its own stock market crash.
} 
In the third phase of the interwar monetary experience, nations faced the avalanche of the global depression. International banking crises, implosion of foreign demand, low investment and battered consumers set forth a vicious cycle. Many nations eventually devalued their exchange rates to gain competitive advantage sparking retaliation. Those that clung to the gold standard tended to raise trade barriers more than other nations in order to offset overvalued exchange rates (Eichengreen and Irwin, 2010). Other nations eliminated the free convertibility of their currencies and imposed a variety of exchange controls (e.g., Germany and other nations in the so-called Reichsmark Bloc). Eichengreen and Sachs (1985) showed that nations that had devalued the most between 1931 and 1935 had the strongest recoveries based on relatively strong performance in industrial production, higher exports, lower real wages and a better investment climate.

The recovery period from 1933 to 1938 represents a fourth phase. Many countries viewed their departures from gold as temporary. Policy makers, and ostensibly their principals, yearned for exchange rate stability in the 1930s. To a certain degree, their interests were served. Instead of coordinated international devaluation and a return to gold, nations formed smaller blocs with smaller countries actively pegging the nominal exchange rate to larger members. Many continued to isolate themselves as much as possible from others with capital controls but maintained stable official exchange rates. The "Sterling Bloc" consisted of many nations in the Commonwealth and also Scandinavia. Straumann and Woitek (2009) discuss the Swedish policy of exchange rate stability against sterling. Canada followed the US after 1933 leading to stable exchange rates between the two nations from 1934. France, Belgium, the Netherlands, Poland and Switzerland carried the mantle of the gold bloc and consequently suffered together 
through a much lengthier depression than other nations. By 1936 this policy had ended. France and Belgium devalued in 1936 and 1935 respectively setting off a recovery based on monetary expansion and re-armament.

The conventional view is that policy makers rejected the gold standard, and by implication, that floating exchange rates dominated. It is striking however that median (nominal) exchange rate volatility across 38 pairs of countries (i.e., the standard deviation of the log change in the nominal exchange rate) is nearly the same between 1926 and 1929 versus 1934 to 1937 (0.013 vs. 0.011). Figure 2 shows that from 1933 (nominal) fixed exchange rates reappeared. At the same time, co-movement in the industrial production indexes rose between 1926 and 1929 and fell between 1934 and 1937. Figure 2 also presents the average value of correlations between the changes in the (filtered) log of industrial production indexes (data and methods are described more thoroughly below and in the data appendix). These are suggestive of the possibility that the return of the international gold standard between 1925 and 1929 indeed drove rising co-movement. International integration in our sample does not seem to be driving the patterns in comovement either as this is flat through the 1920 s when co-movement rises, falling 1929 1933 when co-movement rises. Another puzzling aspect of Figure 2 is why the relatively fixed exchange rates and a revival of trade post-1933 were associated with falling comovement if indeed fixed exchange rates and trade contribute to more co-movement. A more disaggregated approach could be useful in sorting out these aggregate patterns, and the large swings in policy and other major events provide a unique testing ground for theories about how these factors matter. 


\section{Recent Empirical Research in Co-Movement: Knowns and Unknowns}

The international business cycle co-movement literature has generally focused on two separate threads. One views co-movement as the realization of shocks that have an underlying correlation structure. This is the common shock view. The other focuses on transmission of shocks via underlying fundamentals such as economic structure, trade, financial connections or monetary regimes. The list of observables used in recent empirical studies that transmit shocks or can account for common shocks is long. We survey some recent work here and relate them to the small number of hard historical facts on business cycle co-movement.

Basu and Taylor (1999) examine business cycles since 1870. The interwar period shows up as an especially volatile period compared to the classical gold standard period and the Bretton Woods and the floating period. Their explanation appears to lie in the autarkic policies of the period. Bordo and Helbling (2003) use factor analysis to demonstrate that the years 1930-1932 witnessed large global shocks mostly emanating from the US also arguing that the gold standard raised co-movement. Perri and Quadrini (2002) find that trade restrictions and real wage rigidities can explain three fourths of the 1930s depression in Italy. Trade in this case was a channel for business cycle transmission since foreign inputs were important for the productivity of the local economy. None of these studies look at the many possible determinants of co-movement in the interwar period jointly and systematically. The list of other factors is long as exemplified in some of the recent literature that we review now.

Frankel and Rose (1998) find that a doubling of the bilateral trade intensity (trade relative to pair GDP) from the median increases business cycle correlation by an 
economically and statistically significant 0.06 . Other studies have also found a positive correlation (e.g., Canova and Dellas, 1993 and Kose et.al., 2003). Still other studies find that find that they cannot replicate the strong empirical relationship between output correlations and trade integration (Kose and Yi, 2006)

In theory the impact on co-movement is ambiguous or at least sensitive to assumptions about why and how nations trade. Output would be more highly correlated when foreign goods are complements as argued in di Giovanni and Levchenko (2009). In the canonical international business cycle model of Backus, Kehoe and Kydland (1992) more trade could be correlated with lower co-movement even when underlying TFP shocks are positively correlated due to the substitutability of goods. Also, in older Keynesian models of the short-run if foreign demand falls and is not replaced by demand in other countries or from domestic sources, then local output will fall in proportion to the size of the foreign demand shock. Such shocks could emanate from two sources shocks to foreign income or rises in the multifarious barriers to trade discussed above.

Debate as to whether monetary coordination is associated with greater comovement also still rages. Eichengreen (1995) argues that the gold standard played an important role in transmitting negative shocks during the Great Depression. Artis and Zhang (1997) find evidence that lower exchange rate volatility is associated with lower co-movement. Clark and van Wincoop (2001) also fail to find evidence for the idea that monetary regimes matter.

Baxter and Koupiritsas (2005) study en encompassing set of potential determinants and find three of them to be "robust" in an analysis of dyadic business cycle 
co-movement. These are bilateral trade, similarity in level of development (but not necessarily similarity of industrial structure), and distance between countries.

In sum, there are many possible determinants of co-movement, but no study to date that we are aware of has used the bilateral regression approach in the interwar period - a period of extreme shocks and a great laboratory for investigation. Below we provide evidence on whether trade flows, the gold standard, global unobserved shocks and other domestic policies mattered for co-movement in the inter-war laboratory.

\section{Methodology and Data}

\section{IV.A Regression models for bilateral co-movement}

To analyze co-movement of industrial output between two countries, we estimate a series of panel regressions of the following form:

$$
\rho_{i j t}=X_{i j t} \beta+\gamma_{i t}+\mu_{j t}+\delta_{t}+\varepsilon_{i j t}
$$

where $i$ and $j$ are countries, $t$ indexes a set of non-overlapping two-year periods 1920$1921,1922-1923,1924-1925, \ldots, 1936-1937, \rho$ is the within-period correlation between the de-trended change in the logarithm of an index of industrial production, $X$ is a set of determinants defined at the bilateral level, $\beta$ a set of coefficients to be estimated, $\gamma$ and $\mu$ represent interactions between country $i$ and $j$ and the vector of period indicator variables collected in $\delta$, and $\varepsilon$ is a mean zero pair-specific error term.

The logic of equation (1) is to relate the co-movement in the cyclical component in industrial production between any two countries to bilateral fundamentals, domestic 
unobservables that affect all partners equally, global shocks, and shocks or transmission mechanisms idiosyncratic to the pair. ${ }^{3}$ Naturally, at this level of aggregation, and without further structure on the model, we are unable to identify whether estimated coefficients on included covariates represent transmission mechanisms or represent shocks associated with the similarity in economic structure or policy.

Bilateral determinants include information on bilateral exchange rates as a measure of similarity in monetary outcomes or policies. Trade flows measure the potential for transmission of shocks in the real economy. Domestic unobservables control for a host of policies such as exchange controls, tariff rises, non-tariff barriers, industrial structure, and so forth. Country-pair fixed effects can also be included to control for pairspecific correlations and similarity in policy or economic structure. Finally period indicators control for common shocks throughout the set of countries. Spatial correlation in the error terms, and hence bias in the estimated standard errors is built into the standard dyadic approach. This is due to the fact that county $i$ appears in multiple observations at any time $t$. We include country level dummies which alleviates this problem as discussed in Case (1991).

We have data on industrial production for ten countries over nine periods for a total of $(10 * 9 * 9) / 2$ or 405 possible observations on 45 dyads. Due to some missing trade observations in six dyads (Canada- Austria, Denmark-Japan, Denmark- Austria, JapanAustria, Norway - Austria, Sweden- Austria) we use a balanced panel with 342 usable

3 See Baxter and Kouparitsas (2004, 2005) Clark and van Wincoop (2001), Imbs (2004), Frankel and Rose (1998), Flood and Rose (2009) and many others for examples of a dyadic approach similar to ours. Other papers like the long-run comparative paper of Bordo and Helbling (2003) use factor analysis and concordance indices to study co-movement. 
observations for 39 dyads in our regressions. We estimate equation (1) by OLS and use robust standard errors clustered on the country pair. ${ }^{4}$

\section{IV.B Data}

\section{IV.B.1 Measuring Production}

We use data on industrial production or a proxy for industrial production which are available at monthly frequencies. Industrial output data has been used before to examine economic performance in the interwar period in Eichengreen and O'Rourke (2010) and Eichengreen (1992c), and Klovland (1998). While industrial output is an imperfect proxy for Gross Domestic Product and is more volatile over the business cycle, it is highly correlated with total output. Indeed, the National Bureau of Economic Research uses industrial output as one of the five main indicators for dating business cycles.

The main industrial output dataset is based on the League of Nations, Monthly Bulletin of Statistics and the International Abstract of Economic Statistics. ${ }^{5}$ Both of these sources aggregate national accounts data into larger datasets. The countries included in this data source are: Austria, Belgium, Canada, France, Japan, United States, and the United Kingdom. Countries were included in the sample if they had a monthly measure of industrial output for the entire period January 1920 through December 1937.

While we refer to all countries' series as industrial output, there are two main ways industrial output is calculated. The most direct way to measure industrial production is to use an index of industrial activity provided by the country's government. This method is used whenever possible. Another method is to use an index of the sum of

\footnotetext{
${ }^{4}$ Multi-way clusters suitable for dyadic panel data have yet to be developed.

5 These data were graciously provided by Jakob Madsen in electronic format.
} 
pig iron production and steel production in tons. This is a valid approach, as pig iron and steel are major industrial products and also have significant backward and forward linkages to other sectors especially other industrial sectors of the economy. For Austria, pig iron and steel is used from 1919-1936 based on League of Nations data, and an industrial production index is used for the remaining years. For Belgium and the United Kingdom, pig iron plus steel is used for the entire period. For Canada, the United States, Japan, and France an index of industrial production is used for the entire period.

Several flaws were corrected in the data. One major problem is that labor conflict and strikes can cause industrial output to plummet even though overall GDP did not fall nearly as sharply. For example, in the United Kingdom, the industrial output index falls from 99.45 in December of 1920 to 0.149551 in June of 1921. The cause of this sharp decline was a major strike in 1921 by coal workers. Mining, being a strategic industry like railways, was controlled by the state during the First World War. When the mines were "de-nationalised" and returned to private hands on March $31^{\text {st }} 1921$, wage reductions were implemented. The strike was called on the same day. Coal rationing was implemented on April $4^{\text {th }}, 1921$, and the strike ended on June $28^{\text {th }}$, the nadir of the industrial production data. A similar strike occurred in 1926 as part of a general strike against wage reductions, this time streaming from the need for wage deflation so that the United Kingdom could return to real-wages consistent with the pre-war gold parity. Here the industrial production index fell from 90.02987 in March of 1926 to 3.364904 in July of 1926, only to recover to above 90 in February of the next year. These histories are important not only because they show many of the economic problems and conflicts of 
the time, but also the pitfalls of using high frequency and limited proxies for industrial production data.

To remedy this problem, a measure of GDP from Mitchell et al. 2009 is used instead for the 1926 period in the United Kingdom. For 1921, a linear trend is imposed from March 1921 to July 1922. Also, Austria's production is below 1 in December of 1932. However, since this is a single large one-month drop, December 1932 for Austria is kept as is as the filtering method will eliminate most of the sharp drop.

Data for Denmark, Norway, and Sweden were used in Klovland (1998). ${ }^{6}$

Klovland uses production indices for the manufacturing and mining sectors to estimate industrial production at a monthly frequency. Sweden has industrial production data from 1925, but Klovland adds data going back to 1919. All the industrial production data for Norway and Denmark are produced using Klovland's method.

\section{IV.B.2 Determinants of Co-Movement}

We use total bilateral trade flows divided by the sum of the two countries' GDPs as a measure of bilateral trade integration. ${ }^{7}$ This variable is highly correlated with geographic variables such as distance and whether nations share a border. In light of the fact that GDP is part of the trade integration measure these two variables are plausible, excluded instrumental variables (as in Frankel and Rose). ${ }^{8}$

6 Jan Tore Klovland graciously shared these data with us.

${ }^{7}$ Data on trade are from Jacks, Meissner, Novy (2009). Sources are described thoroughly therein. Some missing data were available from Barbieri (1996).

${ }^{8}$ Other theoretically consistent measures of bilateral integration, first developed by Head and Ries (2001), are available and are used for instance by Jacks, Meissner and Novy (2008). Regression results are robust and even more precisely estimated when using this measure, but they involve more explanation for their derivation. For the sake of brevity we rely on trade shares. 
To examine whether the data are consistent with the possibility that the gold standard transmitted shocks, we constructed a gold standard variable that measures how many months out of the 24 months in each period both countries were on gold de facto and de jure. Sources for these dates include Brown (1940), Wandschneider (2005) and Eichengreen and Sachs (1985).

To determine whether countries are de facto pegged or not we use an approach similar to that in Shambaugh (2004). In Shambaugh's classification, countries that stay within a $2 \%$ band in 11 of 12 months (for a given year) are considered as pegged, while countries that are outside of the band for at least 2 months in a year are considered to be de-facto floats. We have modified that approach slightly, as we are using two-year periods. We construct the variable "peg" equal to 1 if the absolute value of the onemonth change in a country's exchange rate is less than $2 \%$ in 21 out of the 24 months. Nominal exchange rates are from Global Financial Data.

An extra month allows for some more flexibility, as even some countries that were in fact on the gold standard still had exchange rates that varied more than $2 \%$ in a month. The issue is "gold points", as gold price arbitrage only occurs once exchange rates are different enough to justify the cost of shipping gold. ${ }^{9}$ This can be more than $2 \%$ in some cases, which will make even countries that are defacto and de jure on the gold standard appear to be floating. There were some countries that had clear de facto pegs without formal announcements. One example is the Canadian dollar, which was essentially at parity with the US Dollar for most of the period (except 1931 to 1934) despite the fact that Canada was only on gold de jure and de facto briefly. We also construct an "average peg" variable which is the fraction of the 24-month period that the

9 See Officer (1996) for more information on gold points 
dyad had a de facto fixed exchange rate. Thus if the dollar-sterling rate is within the $2 \%$ band in 18 out of 24 months from January 1920 to December 1921, then this average peg variable would equal 0.75 .

Related to the exchange rate regime is the level of the exchange rate. The view from Eichengreen and Sachs (1985) is that depreciation allowed nations relief from the Depression. It remains unclear whether such an escape from gold diminished comovement or simply changed the level of output. Using nominal exchange rates from the Global Financial Database we created the absolute value of the difference between the $\log$ nominal exchange rate between January of the first year in the period and December of the next year.

We also include a set of indicator variables for each country in the dyad that are interacted with the period indicators. These time varying country fixed effects controls for unobservable shocks and transmission mechanisms at the country level within each period affecting co-movement with all other countries. It is not hard to think of policies and forces that acted "multilaterally" instead of bilaterally but which are extremely hard to measure directly. These include trade policy and tariffs, exchange controls, the effective multilateral exchange rate regime, fiscal policies, financial crises and so forth. Naturally we include the constituent terms of these interactions such as time-invariant country fixed effects and a set of period dummies. The latter also control for global shocks that affect all countries equally including a scramble for gold reserves, an international liquidity crisis in the world's financial system, commodity price shocks etc. In some specifications we are even able to control for country-pair fixed effects so as to control for (unobservable) similar policies and structures at the country pair level. 


\section{IV.C Filtering Methods}

Before generating business cycle correlations, one must first define the business cycle. All models of the business cycle separate the observed time series of logged economic activity into a business cycle component, which is kept, and other components (e.g., a trend) of logged activity, which are removed. Medium-run components of the relevant time series have been the focus of business cycle research since Burns and Mitchell (1946) identified GDP components having a wavelength of 6 to 32 quarters as defining the American business cycle. This is the approach we take as well. Several filtering technologies exist such as the Christiano-Fitzgerald, Baxter King, Hodrick Prescott (HP) and simple log-linear detrending. We discuss the merits of each in turn though our main results use the Christiano-Fitzgerald filter.

The Hodrick Prescott or the HP filter is a common filter used in business cycle analysis (Hodrick and Prescott, 1997). It is similar to a high-pass filter which removes low-frequency trend components of the data, leaving the medium-to-high frequency data (cycle). While the HP filter is still frequently used, it has some major flaws. ${ }^{10}$ The ideal weighting of trend and cycle is difficult to identify, and the inclusion of high frequency components in the cycle makes identifying the medium-run components much harder to identify.

Another detrending method is to simply remove a linear trend from the logarithm of the time series. This corresponds to constant and unvarying exponential growth rate in industrial output. Here, any deviation from the trend represents the business cycle. This is the most "Keynesian" of the four filtering methods, as potential GDP doesn't fluctuate

10 Cogley and Nason (1995) have a good discussion of some of the shortcomings of the HP filter 
and productivity shocks play no role (even implicitly). This makes for the largest output gaps of any filtering method, as deviation from a constant-growth trend does not change the trend line at all. While the linear trend filtering method does produce a stationary series and linear trends don't produce spurious cycles like the other filtering methods, the linear trend keeps a lot of the noise in the data which is not part of the business cycle

While linear detrending methods do not induce phase shift, they also do not remove unit-root processes, which is problematic. ${ }^{11}$ The HP filter will eliminate unit roots and has no phase shift. The HP filter is essentially a high pass filter that only eliminates high frequency wavelengths while keeping low and medium-wavelength components of the data. While the HP filter does improve over linear detrending, bandpass filters are overall an improvement over the HP filter as they are more flexible, easier to implement, and provide a better approximation to an ideal, infinite order filter. ${ }^{12}$

Popular band pass filters include the Baxter-King and Christiano-Fitzgerald filters. Baxter and King (1995) lay out a band-pass filter which only preserves medium frequency data and filters out low and high frequency data. We set the minimum wavelength to 18 months and the maximum wavelength to 96 months in keeping with the Burns-Mitchell definitions. We set $K=12$ which makes it a moving-average of length 12 . This means that a year of data is lost at the beginning and end of the sample. The Baxter-King filter is well suited to the examination of business cycles as defined by Burns-Mitchell, as it can preserve only components from 1.5 to 8 years.

Christiano and Fitzgerald (2003) develop another band-pass filter which assumes (perhaps falsely) that the underlying data is a random walk. However, this assumption

${ }^{11}$ Phase shift is when a series is shifted horizontally while the frequency remains constant 12 See Baxter and King (1995). 
results in a nearly optimal filter and a more variable business cycle than the Baxter-King Filter. The Christiano Fitzgerald (CF) filtered industrial output dataset is parameterized as follows. The band is between 18 and 96, as this corresponds to the number of months in Burns-Mitchell's definition of the business cycle as 1.5 to 8 years. The lead-lag length is 12, as is recommended in the literature, specifically Christiano and Fitzgerald (2003) and Baum (2006). This means that a year of data is lost at the beginning and end of the period. As seasonal variations are annual and thus based on a 12-month wavelength, a band pass filter like CF that removes cycles with wavelength smaller than 18 months will automatically remove any seasonal component from the data. Thus for the core dataset of 1920-1937, the years of 1919 and 1938 are not included on their own but are needed to construct the filtered data for the core years.

The CF is our preferred filter, as it contains several interesting characteristics. Most importantly, it is a band-pass filter, so it filters out the noise component. Secondly, it does not assign as much of the data to the trend as the Baxter-King filter does. This is important because if nominal GDP simply equals potential GDP then there is no cycle and nothing to analyze. In sum, the CF filter provides a good compromise between Keynesian type models where the business cycle is simply deviations from the linear trend, and RBC type models where trend GDP fluctuates greatly over the business cycle.

\section{Results}

Figure 3 presents evidence on the overall evolution of co-movement using several different filtering methods. The mean correlation across all pairs ranges from a low of -0.04 (1934-35) at the beginning of the recovery from the Depression to a high of 0.90 
(1928-29) at the start. The average level of co-movement - on the order of 0.06 - is similar in 1926-27 and 1936-37. The global shock being transmitted via the gold standard is quite visible as the $10^{\text {th }}$ and the $90^{\text {th }}$ percentile squeezes rapidly upward between 1928 and 1931. Before, and after, the range of experience is large as the spread between the $90^{\text {th }}$ and $10^{\text {th }}$ deciles reveals.

Table 1 presents results from a regression like that of equation (1). The key variables are the level of trade integration and the percentage of the time period a dyad has a de-facto fixed exchange rate. Here, percent of time pegged has a large and significant effect on business cycle co-movement, while trade is not significant. The impact of a one standard deviation rise in the "average fixed" variable $(=0.29)$ is associated with a rise in the correlation of 0.16 or $1 / 4$ of a standard deviation of the dependent variable.

Trade appears as a significant determinant of business cycle co-movement but only after controlling for the endogeneity of the trade share variable. The instrumental variable estimation in column (2) uses the gravity-inspired variables - border and distance - as excluded instruments. This regression shows that trade has a positive association with co-movement and it is now more precisely estimated ( $p$-value $=0.056)$. A doubling of the median bilateral trade share from 0.16 to 0.32 is associated with a rise in correlation of 0.06 . The significance and magnitude of the peg decreases in this specification due to some correlation between the two variables. ${ }^{13}$ Figures 4 and 5

\footnotetext{
${ }^{13}$ Results in columns 1 and 2 are robust to using the logarithm of the trade share instead of the level. Using the logarithm of the trade cost measure discussed in Jacks, Meissner and Novy (2008) and distance and border as instrumental variables for it, the log of trade costs has a coefficient of -0.278 and a standard error of 0.118 .
} 
present added-variable scatter plots of the relationships between co-movement, trade and fixed exchange rates.

In Figure 6 we show the impact of trade flows versus exchange rate regimes using counterfactual predictions. First we show the predicted values of the correlation value from the model of Table 1 column 2. Next the line labeled "1928-29" peg uses the same model but predicts correlations using the bilateral value of the fixed exchange rate variable in 1928-29. The 1928-29 trade values line predicts using the trade values from 1928-29 and the actual values for other variables. It is quite clear that co-movement would have been much higher in the 1920s and in the early 1930s had nations all been bound together by a system of fixed exchange rates. The average predicted correlation would have been 0.25 higher in 1932-33 in a counterfactual world where nations maintained their fixed exchange rates. However, there does not seem to be much difference between the predicted values for the post-1933 period either with 1928 fixed exchange rate values or with the actual values. This must be because of the resurgence of fixed exchange rates after 1933.

Still, the overall fall in correlations after 1933, when trade was recovering and exchange rates were less volatile is surprising. The explanation is that inter-bloc exchange rate volatility fell more slowly or rose while intra bloc volatility fell more quickly. This induced an overall lower average correlation via inter-bloc correlations that were falling more quickly than intra-bloc correlations. A casual look at those in blocs after 1932 (US-Canada, UK-Scandinavia, and France-Belgium) suggests that this is indeed the cause of this empirical outcome. The average correlation amongst pairs within the sterling bloc, gold bloc or dollar bloc was 0.29 in $1932-33$ and 0.11 between 1934- 
1937. On the other hand, output correlation fell faster for those nations not sharing a fixed exchange rate. For those pairs not in a currency bloc, the values were 0.34 and 0.03 respectively.

\section{Robustness Checks}

The third regression in Table 1 includes country-pair fixed effects and it is consistent with the first column. Trade however is statistically insignificant and has a negative sign. It is likely that the trade values are highly correlated with the fixed effects either because most of the variation is across countries rather than over time. The negative sign could also signal the endogeneity of changes in trade to the co-movement variable, but our instruments are impossible to use since they do not vary over time.

Columns (4) and (5) of Table 1 introduce an interaction term between trade and the exchange rate regime. Trade may induce more co-movement when the exchange rate is more rigid. The interaction term is not significant, though the fixed exchange rate term is very significant again. The signs of the interactions imply that the impact of trade is smaller when nations have fixed exchange rates. This interaction effect is positive when we use interactions of the gravity variables with the exchange rate regime as instrumental variables. However, once again, the interaction term is not significant. Column 6 looks into whether the level of the exchange rate or bilateral stability mattered more. The level of the exchange rate is statistically insignificant while the peg variable is still significant with a very similar point estimate to that in column 2 .

It should also be highlighted that all regressions in Table 1 include time effects for common shocks, time-varying country fixed effects and country-level time-invariant 
indicators. Based on the time dummies in regressions without time-varying country fixed effects we find strong evidence for common shocks between 1928 and 1932. Here 192829 and 1930-31 have large and significant intercepts. The fact that trade flows are highly significant with the exclusion of the time-varying county-dummies (this is left unreported) also suggests to us that trade policy at the multilateral level changed correlations significantly.

Table 2 examines the relationships between co-movement, trade, the gold standard, and exchange rate depreciation. Column 1 includes the trade variable and a variable that records the percentage of a two-year period that both countries are on the gold standard. Both variables are significant and positive. Next, an interaction between trade and the gold standard variable is added, and all variables show up as significant. In this case, the interaction of gold and trade is negative. This would imply that the marginal effect of trade on co-movement is smaller the more likely a country-pair is on the gold standard. This is an unintuitive result, but could reflect the fact that gold standard countries were more prone to raise tariffs in an effort to obtain external balance.

The third regression of Table 2 examines exchange rate depreciation and trade. Here depreciation does not show up as significant, though trade does. Exchange rate depreciation could drive business cycles apart through expenditure switching and gold flows, but this does not appear to be the case. The reason is that after nations undertook depreciation in the interwar period they usually re-pegged their exchange rates bringing their co-movement back in line with other nations. Column 5 confirms that fixed exchange rates, rather than depreciation, is driving co-movement. Nations on the gold standard have higher co-movement while depreciation is insignificant. Trade, as in 
previous columns, remains significant. When we instrument for trade in these specifications (un-reported) all results are qualitatively similar and trade remains statistically significant.

Table 3 presents a series of regressions to see whether the results are robust to the filtering methodology. We present two regressions for each of the three following filtering methods: Baxter-King, Hodrick-Prescott and the linear time trend. Each regression includes, as before, time dummies, time-varying country fixed effects and country fixed effects. Results are largely in line with earlier models using the Chirstiano Fitzgerald filter. Trade and exchange rate pegs are associated with a greater deal of comovement.

\section{Some Tentative Conclusions}

The interwar period yielded extremely volatile business cycles for most countries. Our results have found that trade and exchange rate regimes played an important role in transmitting business cycles during this period. These results conform with the more modern post-World War II literature on determinants of business cycle co-movement.

Still, these correlations are not obvious in the aggregate data. In fact a puzzling aspect of the aggregate data exists. As exchange rate regimes made a comeback and trade recovered in the 1930s, the average level of co-movement actually fell to a within period low. Much of the reduction in correlation seems to be due to low inter-bloc correlation with higher intra-bloc correlation. The group of nations that once adhered en masse to a gold standard splintered into several constituent blocs that amongst them were highly asynchronous. 
The interwar experience also supplies further information regarding the robust determinants of co-movement. Similar determinants in the interwar period mattered as in the modern, post-Bretton Woods period. Evidence consistent with the idea that the gold standard transmitted business cycles is also found with a novel methodology. While the breakdown of the gold standard in the 1930s was necessary to see recovery from the Great Depression, this was not the final nail in the coffin of integration. Nations revealed a preference for coordinated monetary policies and trade persisted keeping them exposed to shocks from abroad. Whether policy makers acted on this information and desired this outcome is an interesting avenue for further research. 


\section{References:}

Adalet, Müge. 2005. "Fundamentals, Capital Flows and Capital Flight: The German Banking Crisis of 1931" mimeo. Victoria University, Wellington.

Amaral, Pedro and James Macgee. 2002. "Data Appendix to The Great Depression in Canada and the United States: A Neoclassical Perspective." Review of Economic Dynamics, 5: 45-72.

Anderson, James, and Eric van Wincoop. 2003. "Gravity with Gravitas: A Solution to the Border Puzzle," American Economic Review, 93(1): 170-192.

Artis, M.J., Zhang, W., 1997 "International business cycles and the ERM: is there a European business cycle?” International Journal of Finance and Economics 2, 116.

Backus , David K., and Patrick J. Kehoe, and Finn E. Kydland. 1992. "International Real Business Cycles." The Journal of Political Economy, 100(4): 745-775.

Bank of International Settlements, http://www.bis.org/about/chronology/1929-1939.htm, Accessed 3/12/2010.

Baum, Christopher. 2006. "Time-Series Filtering Techniques in Stata”, Department of Economics, Boston College.

Barbieri, Katherine, 1996. "Economic Interdependence and Militarized Interstate Conflict, 1870-1985.” PhD dissertation, Binghampton University.

Basu , Susanto and Alan M. Taylor. 1999. "Business Cycles in International Historical Perspective.” The Journal of Economic Perspectives, 13(2): 45-68.

Baxter, Marianne and R. G. King. 1999. "Measuring Business Cycles: Approximate Band-Pass Filters for Economic Time Series." Review of Economics and Statistics, 81: 575-93.

Baxter , Marianne and Michael A. Kouparitsas. 2003. "Trade Structure, Industrial Structure, and International Business Cycles." The American Economic Review Papers and Proceedings, 93(2): 51-56.

Baxter, Marianne and Michael A. Koupiritsas. 2005. "Determinants of business cycle comovement: a robust analysis.” Journal of Monetary Economics, 52(1) 113-157 
Baxter, Marianne, and Alan C. Stockman. 1989. "Business cycles and the exchange-rate regime : Some international evidence." Journal of Monetary Economics, 23(3):377-400

Michael Bordo, Chris Erceg and Charles Evans (2000). "Money, Sticky Wages and the Great Depression”. American Economic Review. 90 (5) pp. 1447-1463.

Bordo, Michael D. and Thomas Helbling. 2003. "Have Business Cycles Become More Synchronized." NBER Working Papers 10130, National Bureau of Economic Research, Inc.

Bordo Michael D. and Finn E. Kydland. 1995. "The Gold Standard As a Rule: An Essay in Exploration" Explorations in Economic History, 32(4):423-464.

Bordo, Michael D. and Anna J. Schwartz. 1998. "Transmission of Real and Monetary Disturbances under Fixed and Floating Exchange Rates" Cato Journal, 8(2):451475.

Brown, William Adams Jr. 1940. The International Gold Standard Reinterpreted: 19141934. New York: National Bureau of Economic Research.

Burns, A. M. and W.C. Mitchell. 1946. Measuring Business Cycles. New York: National Bureau of Economic Research.

Canova, Fabio and Harris Dellas. 1993. "Trade interdependence and the international business cycle," Journal of International Economics, 34(1-2):23-47.

Case, Anne. 1991. "Spatial Patterns in Household Demand," Econometrica, 59, 953-965.

Child, Frank C. 1958. The theory and practice of exchange control in Germany : a study of monopolistic exploitation in international markets The Hague: M. Nijhoff.

Choudhri, Ehsan U. and Levis A. Kochin. 1980. "The Exchange Rate and the International Transmission of Business Cycle Disturbances: Some Evidence from the Great Depression “ Journal of Money, Credit and Banking, 12(4):565-574.

Christiano, Lawrence J. and Terry J. Fitzgerald. 2003. "The Band Pass Filter." International Economic Review, 44(2): 435-465.

Clark, Todd E. and Erin van Wincoop. 2001. "Borders and Business Cycles." Journal of International Economics, 55(1): 59-85.

Cogley, Timothy and James M. Nason. 1995. "Effects of the Hodrick-Prescott filter on trend and difference stationary time series Implications for business cycle research," Journal of Economic Dynamics and Control, 19(1-2):253-278. 
Cole , Harold L. and Lee E. Ohanian, 1999. "The Great Depression in the United States from a neoclassical perspective," Quarterly Review, Federal Reserve Bank of Minneapolis, issue Win, 2-24.

Cole, Harold L. and Lee E. Ohanian. 2002. "The Great U.K. Depression: A Puzzle and Possible Resolution," Review of Economic Dynamics, 5(1): 19-44.

Crucini, Mario J. and James Kahn. 1996. "Tariffs and aggregate economic activity: Lessons from the Great Depression." Journal of Monetary Economics, 38(3): 427467.

di Giovanni, Julian and Andrei Levchenko. 2009. "Putting the Parts Together: Trade, Vertical Linkages, and Business Cycle Comovement," American Economic Journal: Macroeconomics, 2:2 (Apr. 2010), 95-124.

Eichengreen, Barry. 1984. "Central bank cooperation under the interwar gold standard," Explorations in Economic History, 21(1):64-87

Eichengreen, Barry. 1992a. Golden Fetters, The Gold Standard and the Great Depression, 1919-1939. New York: Oxford University Press.

Eichengreen, Barry, 1992b. "More speculation on destabilizing speculation." Explorations in Economic History, 29(1): 93-98.

Eichengreen, Barry. 1992c. "The Origins and Nature of the Great Slump Revisited." The Economic History Review, 45(2): 213-239.

Eichengreen, Barry and Douglas A. Irwin. 1995. "Trade Blocs, Currency Blocs, and the Reorientation of World Trade in the 1930s." Journal of International Economics, 38(1): $1-24$.

Eichengreen, Barry and Kevin H. O’Rourke. 2010 “A Tale of Two Depressions: What do the new data tells us?" Voxeu, http://www.voxeu.org/index.php?q=node/3421 accessed 3/10/2010

Eichengreen, Barry and Jeffrey Sachs. 1985. "Exchange Rates and Economic Recovery in the 1930s" The Journal of Economic History, 45(4):925-946.

Eichengreen, Barry, and Jeffrey Sachs. 1986. "Competitive Devaluation and the Great Depression," Economics Letters, 22:67-71.

Ferguson, Thomas and Peter Temin. 2003. "Made in Germany: The German Currency Crisis of July 1931," Research in Economic History, 21: 1-53. 
Flood, R. and Rose, A. 2009. "Inflation Targeting and Business Cycle Synchronization." CEPR Discussion Paper no. 7377. London, Centre for Economic Policy Research.

Frankel , Jeffrey A., and Andrew K. Rose. 1998. "The Endogeneity of the Optimum Currency Area Criteria," The Economic Journal, 108(449): 1009-1025.

Gleditsch, Kristian Skrede \& Michael D. Ward. 2001. "Measuring Space: A Minimum Distance Database and Applications to International Studies," Journal of Peace Research 38:739-58.

Global Financial Data [Online]. 3/10/2010. Available: Global Financial Data.

Head, Keith and John Ries. 2001. "Increasing Returns Versus National Product Differentiation as an Explanation for the Pattern of US-Canada Trade." American Economic Review 91(4): 858-876.

Hodrick, Robert, and Edward C. Prescott. 1997. "Postwar U.S. Business Cycles: An Empirical Investigation," Journal of Money, Credit, and Banking, 29(1), 1-16.

Imbs, Jean. 2004. "Trade, Finance, Specialization, and Synchronization." Review of Economics and Statistics, 86(3): 723-734.

Jacks, David, Christopher Meissner, and Dennis Novy. 2008. "Trade Costs, 1870-2000." American Economic Review, Papers \& Proceedings 98(2): 529-534.

Kalemli-Ozcan, Sebnem and Elias Papaioannou and José Luis Peydró. 2010. "Financial Regulation, Integration and Synchronization of Economic Activity," TÜSİAD-KOÇ University Economic Research Forum Working Papers 1005, TUSIAD-Koc University Economic Research Forum.

Kehoe, Timothy J. and Edward C. Prescott. 2007. Great Depressions of the Twentieth Century. Minneapolis: Federal Reserve Bank of Minneapolis.

Kindleberger, Charles P., 1973. The World in Depression 1929-1939. Berkeley: Univ. of California Press.

Klovland, Jan T. 1998. "Monetary Policy and business cycles in the interwar years: The Scandinavian experience." European Review of Economic History, 2:309-344.

Kose, M. Ayhan, and Eswar S. Prasad, and Marco E. Terrones. 2003. "How Does Globalization Affect the Synchronization of Business Cycles?" The American Economic Review, Papers and Proceedings, 93(2):57-62. 
Kose, M. Ayhan and Kei-Mu Yi. 2006. "Can the standard international business cycle model explain the relation between trade and co-movement?" Journal of international Economics, 68(2):267-295.

League of Nations. 1920-1940. Monthly Bulletin of Economic Statistics. Geneva: League of Nations

Lopez-Cordova, J. Ernesto and Christopher M. Meissner. 2003. "Exchange-Rate Regimes and International Trade: Evidence from the Classical Gold Standard Era," American Economic Review, 93(1):344-353.

Madsen, Jakob. 2001. "Agricultural crises and the international transmission of the great depression," Journal of Economic History, 61: 327-365.

Madsen, Jakob B. 2001b. "Trade Barriers and the Collapse of World Trade during the Great Depression.” Southern Economic Journal 67(4): 848-868.

Mitchell, J., and S. Solomou, and M. Weale. 2009. "Monthly and Quarterly GDP Estimates for Interwar Britain." Cambridge Working Papers in Economics 0949, Faculty of Economics, University of Cambridge.

Nurkse, Ragnar. 1944. International Currency Experience. Geneva: League of Nations.

Officer, Lawrence H. 1996. Between the Dollar-Sterling Gold Points: Exchange Rates, Parity, and Market Behavior. Cambridge: Cambridge University Press.

Perri, Fabrizio and Vincenzo Quadrini. 2002. "The Great Depression in Italy: Trade Restrictions and Real Wage Rigidities," Review of Economic Dynamics, 5(1): 128-151.

Perkins, Anne. 2006. A very British strike: 3 May-12 May, 1926. London: Macmillan

Richardson, Gary and van Horn Patrick. 2007. "Fetters of Debt, Deposit, or Gold during the Great Depression? The International Propagation of the Banking Crisis of 1931” NBER working paper 12983.

Ritschl, Albrecht and Nikolaus Wolf. 2003. "Endogeneity of currency areas and trade blocs: evidence from the inter-war period." CEPR Discussion Papers 4112, C.E.P.R. Discussion Papers.

Romer, Christina D. 1992. "What Ended the Great Depression?" Journal of Economic History, 52(4): 757-784.

Rose, Andrew K. and Charles Engel. 2002. "Currency Unions and International Integration.” Journal of Money, Credit, and Banking, 34(4):1067-1089 
Shambaugh , Jay C., 2004. "The Effect of Fixed Exchange Rates on Monetary Policy," The Quarterly Journal of Economics, 119(1):300-351.

Straumann, Tobias and Woitek, Ulrich (2009) "A pioneer of a new monetary policy? Sweden's price-level targeting of the 1930s revisited" European Review of Economic History vol. 13 pp. 251-282.

Symons, J. 1957. The General Strike. London: Cresset Press.

Tinbergen, Jan. 1934. International Abstract of Economic Statistics. International Conference of Economic Services.

Wandschneider, Kirsten. 2005. "The stability of the Inter-war Gold Exchange Standard. Did Politics Matter?" The Journal of Economic History, 68(1): 151-181.

Wolf, Nikolaus. 2008. "Scylla and Charybdis. Explaining Europe's exit from gold, January 1928-December 1936." Explorations in Economic History, 45(4):383401. 
Table 1 Co-movement, exchange rate regimes and trade for 38 country pairs, 1920-1938

\begin{tabular}{|c|c|c|c|c|c|c|}
\hline & $\begin{array}{c}(1) \\
\text { Baseline }\end{array}$ & $\begin{array}{c}(2) \\
\text { IV } \\
\text { Baseline }\end{array}$ & $\begin{array}{c}(3) \\
\text { Country-pair } \\
\text { Fixed Effects }\end{array}$ & $\begin{array}{c}(4) \\
\text { Interaction }\end{array}$ & $\begin{array}{c}(5) \\
\text { Interaction } \\
\text { with IV }\end{array}$ & $\begin{array}{c}(6) \\
\text { Depreciation vs. } \\
\text { Percent of time pegged }\end{array}$ \\
\hline \multicolumn{7}{|l|}{$=$} \\
\hline Trade as a share of GDP & $\begin{array}{c}0.0413 \\
{[0.0505]}\end{array}$ & $\begin{array}{c}0.195^{\star} \\
{[0.0991]}\end{array}$ & $\begin{array}{l}-0.1410 \\
{[0.156]}\end{array}$ & $\begin{array}{c}0.0797 \\
{[0.0648]}\end{array}$ & $\begin{array}{l}0.0774 \\
{[0.114]}\end{array}$ & $\begin{array}{c}0.198^{*} \\
{[0.010]}\end{array}$ \\
\hline Percent of time pegged & $\begin{array}{c}0.566^{\star \star \star} \\
{[0.177]}\end{array}$ & $\begin{array}{l}0.333^{\star} \\
{[0.19]}\end{array}$ & $\begin{array}{c}0.711^{\star \star \star} \\
{[0.214]}\end{array}$ & $\begin{array}{c}0.577^{\star \star \star} \\
{[0.18]}\end{array}$ & $\begin{array}{l}0.3190 \\
{[0.205]}\end{array}$ & $\begin{array}{c}0.337^{*} \\
{[0.189]}\end{array}$ \\
\hline Interaction of trade and time-pegged & --- & --- & --- & $\begin{array}{l}-0.0577 \\
{[0.134]}\end{array}$ & $\begin{array}{c}.161 \\
{[0.224]}\end{array}$ & --- \\
\hline Absolute depreciation vs gold parity & --- & --- & --- & --- & --- & $\begin{array}{l}0.0300 \\
{[0.044]}\end{array}$ \\
\hline Observations & 342 & 342 & 342 & 342 & 342 & 342 \\
\hline R-Squared & 0.702 & 0.696 & 0.702 & 0.702 & .695 & .695 \\
\hline
\end{tabular}

\section{Estimation is by OLS}

Robust standard errors in brackets, clustered by country-pair

Left hand side variable is the bilateral correlation of the Christiano-Fitzgerald filtered industrial output index

Period, country dummies, and time varying country fixed effects are included but not reported

${ }^{*}$ significant at $<10 \%$; ** significant at $<5 \%$; ${ }^{* * *}$ significant at $<1 \%$

Table 2 Co-movement, the gold standard and trade for 38 country pairs, 1920-1938

\begin{tabular}{|c|c|c|c|c|c|}
\hline & $\begin{array}{c}(1) \\
\text { Baseline } \\
\text { Gold }\end{array}$ & $\begin{array}{c}(2) \\
\text { Interaction } \\
\text { Trade \& Gold }\end{array}$ & $\begin{array}{c}(3) \\
\text { Baseline } \\
\text { Depreciation }\end{array}$ & $\begin{array}{c}(4) \\
\text { Interaction } \\
\text { Trade \& Depreciation }\end{array}$ & $\begin{array}{c}(5) \\
\text { Depreciation vs. } \\
\text { Gold }\end{array}$ \\
\hline Trade as share of GDP & $\begin{array}{c}0.0740^{*} \\
{[0.0411]}\end{array}$ & $\begin{array}{c}0.146^{\star \star \star} \\
{[0.046]}\end{array}$ & $\begin{array}{l}0.0981^{\star *} \\
{[0.0393]}\end{array}$ & $\begin{array}{c}0.0458 \\
{[0.0637]}\end{array}$ & $\begin{array}{c}0.076^{\star \star \star} \\
{[0.041]}\end{array}$ \\
\hline Both on Gold Standard & $\begin{array}{c}0.745^{\star \star \star} \\
{[0.212]}\end{array}$ & $\begin{array}{c}0.840^{\star \star * *} \\
{[0.21]}\end{array}$ & --- & --- & $\begin{array}{c}0.751^{\star \star \star} \\
{[0.212]}\end{array}$ \\
\hline Interaction of Gold and Trade & --- & $\begin{array}{l}-0.251^{\star *} \\
{[0.0927]}\end{array}$ & --- & --- & --- \\
\hline Depreciation & --- & --- & $\begin{array}{l}-0.0033 \\
{[0.0518]}\end{array}$ & $\begin{array}{l}-0.0244 \\
{[0.0547]}\end{array}$ & $\begin{array}{c}.028 \\
{[0.050]}\end{array}$ \\
\hline Interaction of trade and depreciation & --- & --- & --- & $\begin{array}{l}0.3930 \\
{[0.365]}\end{array}$ & --- \\
\hline $\begin{array}{l}\text { Observations } \\
\text { R-Squared }\end{array}$ & $\begin{array}{c}342 \\
0.712\end{array}$ & $\begin{array}{c}342 \\
0.716\end{array}$ & $\begin{array}{c}342 \\
0.696\end{array}$ & $\begin{array}{c}342 \\
0.700\end{array}$ & $\begin{array}{l}342 \\
.713\end{array}$ \\
\hline
\end{tabular}

Estimation is by OLS

Robust standard errors in brackets, clustered by country-pair

Left hand side variable is the bilateral correlation of the Christiano-Fitzgerald filtered industrial output index

Period, country dummies, and time varying country fixed effects are included but not reported

* significant at $<10 \%$; ** significant at $<5 \%$; ** significant at $<1 \%$ 
Table 3 Co-movement trade and exchange rate regimes: alternative filtering methods

\begin{tabular}{|c|c|c|c|c|c|c|}
\hline & $\begin{array}{c}(1) \\
\text { Baxter-King }\end{array}$ & $\begin{array}{c}(2) \\
\text { Baxter-King } 2\end{array}$ & $\begin{array}{c}\text { (3) } \\
\text { Hodrick-Prescott }\end{array}$ & $\begin{array}{c}(4) \\
\text { Hodrick-Prescott }\end{array}$ & $\begin{array}{c}\text { (5) } \\
\text { Linear-trend }\end{array}$ & $\begin{array}{c}(6) \\
\text { Linear-trend }\end{array}$ \\
\hline Trade as share of GDP & $\begin{array}{l}0.212^{\star \star *} \\
{[0.0558]}\end{array}$ & $\begin{array}{c}0.136^{\star *} \\
{[0.0521]}\end{array}$ & $\begin{array}{l}0.0718^{* *} \\
{[0.0292]}\end{array}$ & $\begin{array}{c}0.0386 \\
{[0.03]}\end{array}$ & $\begin{array}{l}0.0739 * * \\
{[0.0282]}\end{array}$ & $\begin{array}{c}0.0344 \\
{[0.0311]}\end{array}$ \\
\hline Both on Gold Standard & $\begin{array}{l}0.710^{\star \star} \\
{[0.283]}\end{array}$ & $\begin{array}{l}-- \\
---\end{array}$ & $\begin{array}{l}0.353^{\star \star} \\
{[0.167]}\end{array}$ & $\begin{array}{l}-- \\
---\end{array}$ & $\begin{array}{c}0.607^{\star \star *} \\
{[0.175]}\end{array}$ & $\begin{array}{l}-- \\
---\end{array}$ \\
\hline Percent of time pegged & $\begin{array}{l}-- \\
---\end{array}$ & $\begin{array}{c}0.992^{\star \star *} \\
{[0.288]}\end{array}$ & $\begin{array}{l}-- \\
---\end{array}$ & $\begin{array}{c}0.445^{\star \star \star} \\
{[0.141]}\end{array}$ & --- & $\begin{array}{c}0.589 * * * \\
{[0.164]}\end{array}$ \\
\hline $\begin{array}{l}\text { Observations } \\
\text { R-Squared }\end{array}$ & $\begin{array}{c}342 \\
0.537\end{array}$ & $\begin{array}{c}342 \\
0.541\end{array}$ & $\begin{array}{c}342 \\
0.771\end{array}$ & $\begin{array}{c}342 \\
0.772\end{array}$ & $\begin{array}{c}342 \\
0.803\end{array}$ & $\begin{array}{c}342 \\
0.796\end{array}$ \\
\hline
\end{tabular}

Standard errors are in brackets

Estimation is by OLS, Clustered by country-pair

LHS variable is the corrbilateral correlation of filtered output using the 3 other methods than Christiano-Fitzgerald.

Period,country dummies, and time varying fixed effects are included but not reported

* significant at $10 \%$; ${ }^{* *}$ significant at $5 \%$; ${ }^{* \star}$ significant at $1 \%{ }^{* \star \star *}$ significant at $0.1 \%$ 
Figure 1 Monthly Industrial Production Indexes for 10 Countries, January, 1920- December, 1938

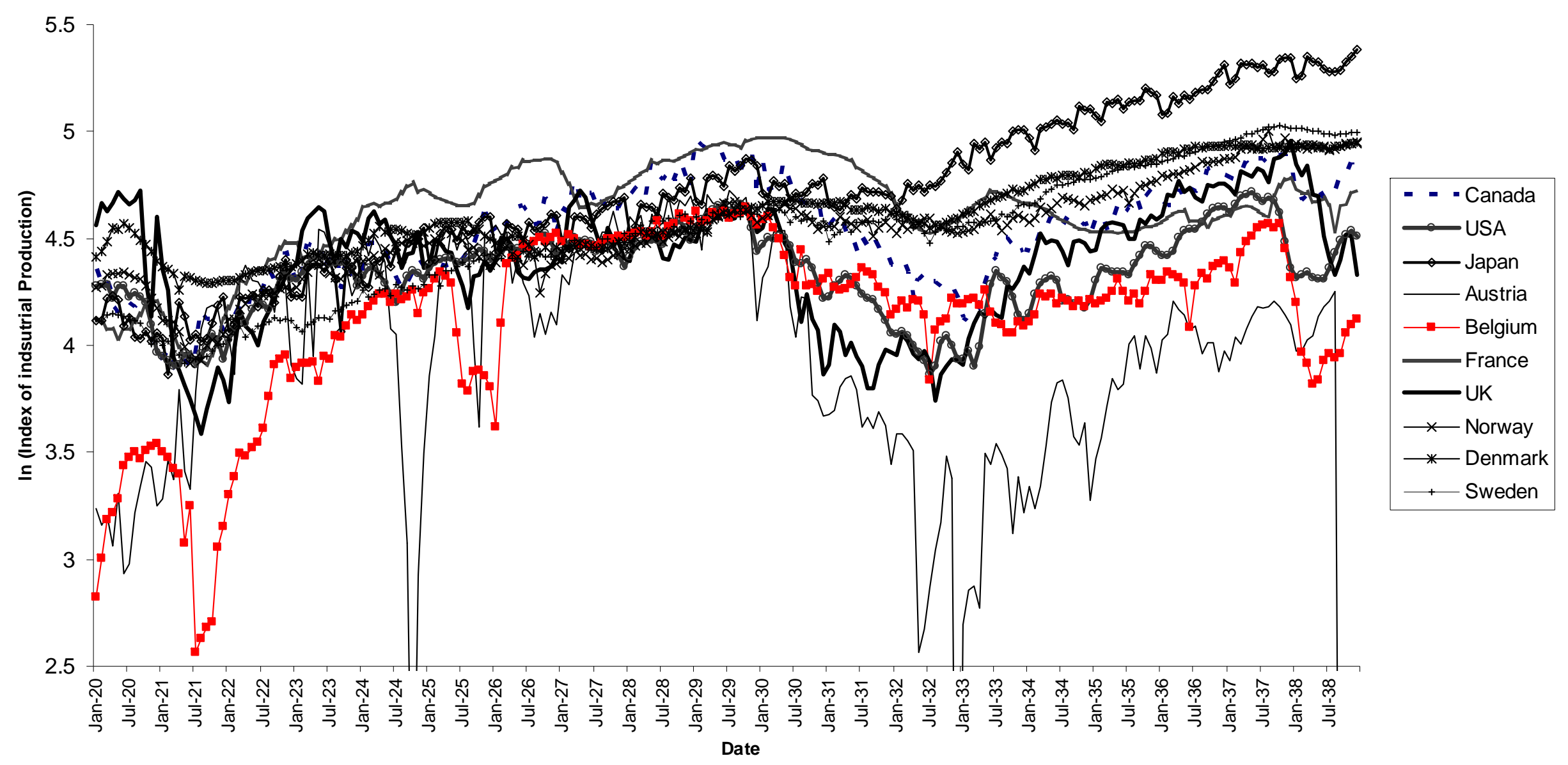

Notes: Data sources are described in the text. Data are monthly observations on the logarithm of industrial production indexes. 
Figure 2 Industrial Output Correlations, Fixed Exchange Rates and Trade Integration, 1920- 1938.

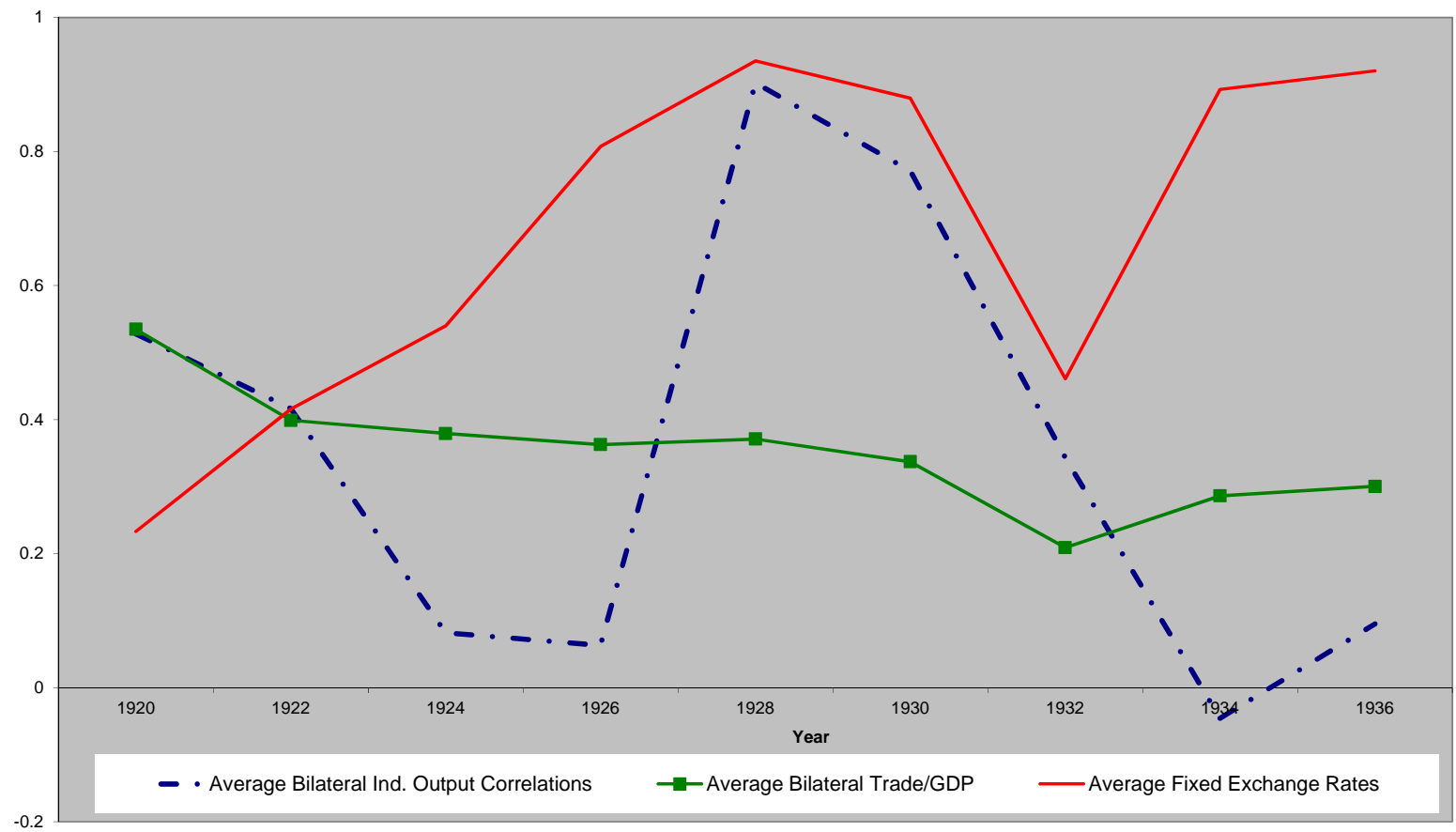

Notes: Sample arithmetic averages of three variables are presented. Bilateral industrial output indexes have been detrended using a Christiano-Fitzgerald filter as described in the text. Correlation is measured over two year periods Bilateral trade is defined as bilateral exports plus imports divided by total pair GDP. The fixed exchange rate variable is defined as the percentage of a two year period in which a country pair has a fixed exchange rate as defined in the text. Data cover 38 country pairs. 
Figure 3 Average bilateral correlation in de-trended industrial production indexes, 19201938

\section{Dyadic IP Correlations}
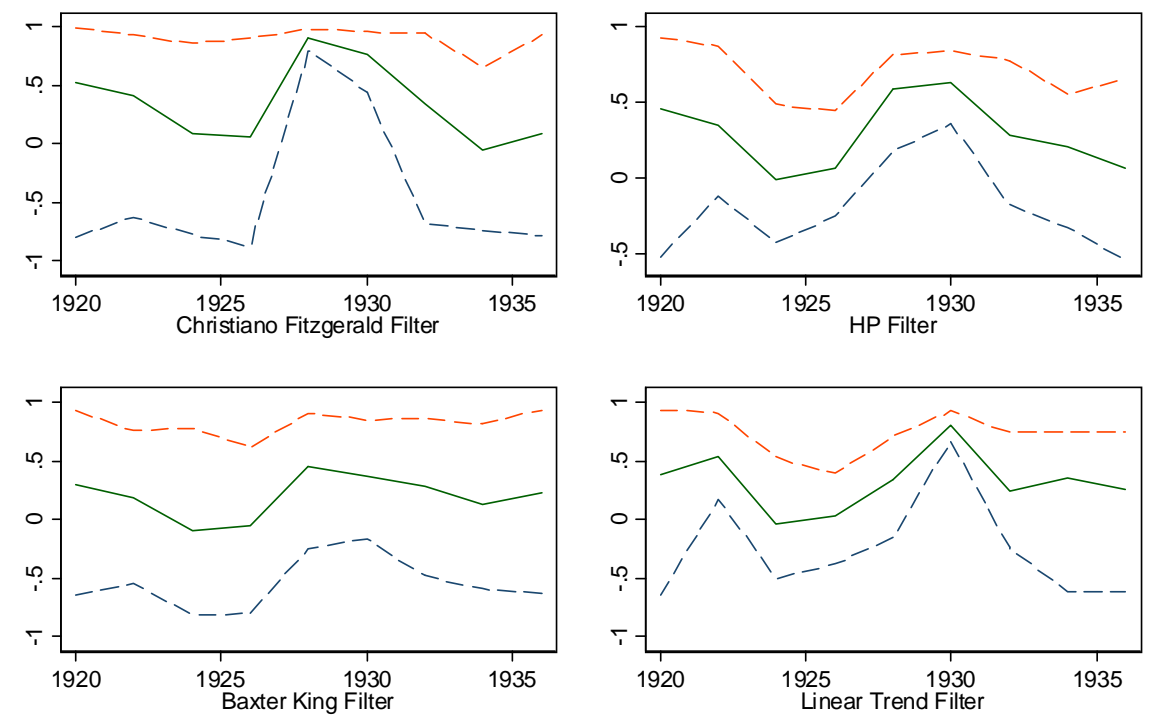

Mean, 90th and 10th percentiles

Notes: Correlations are at the country pair level and defined over non-overlapping two year periods beginning in January 1920. Data cover 38 country pairs. The logarithms of the indexes are de-trended using the filtering method in the legend above.

Figure 4 Added-Variable Scatter Plot for a Regression of Correlation in Industrial Production and the Bilateral Trade Share

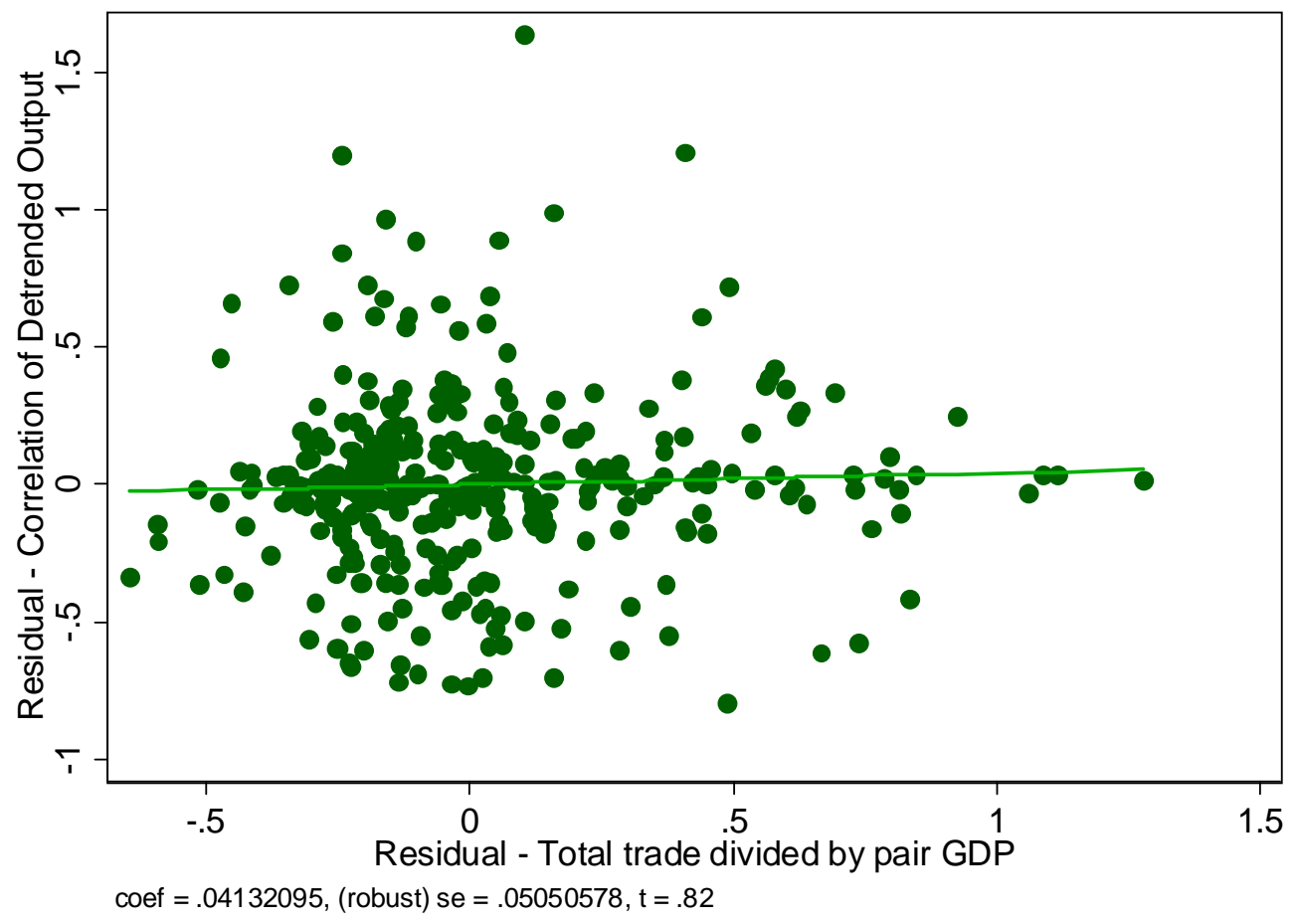


Figure 5 Added-Variable Scatter Plot for a Regression of Correlation in Industrial Production and the Percentage of the Time Period a Dydad had Fixed Exchange Rates

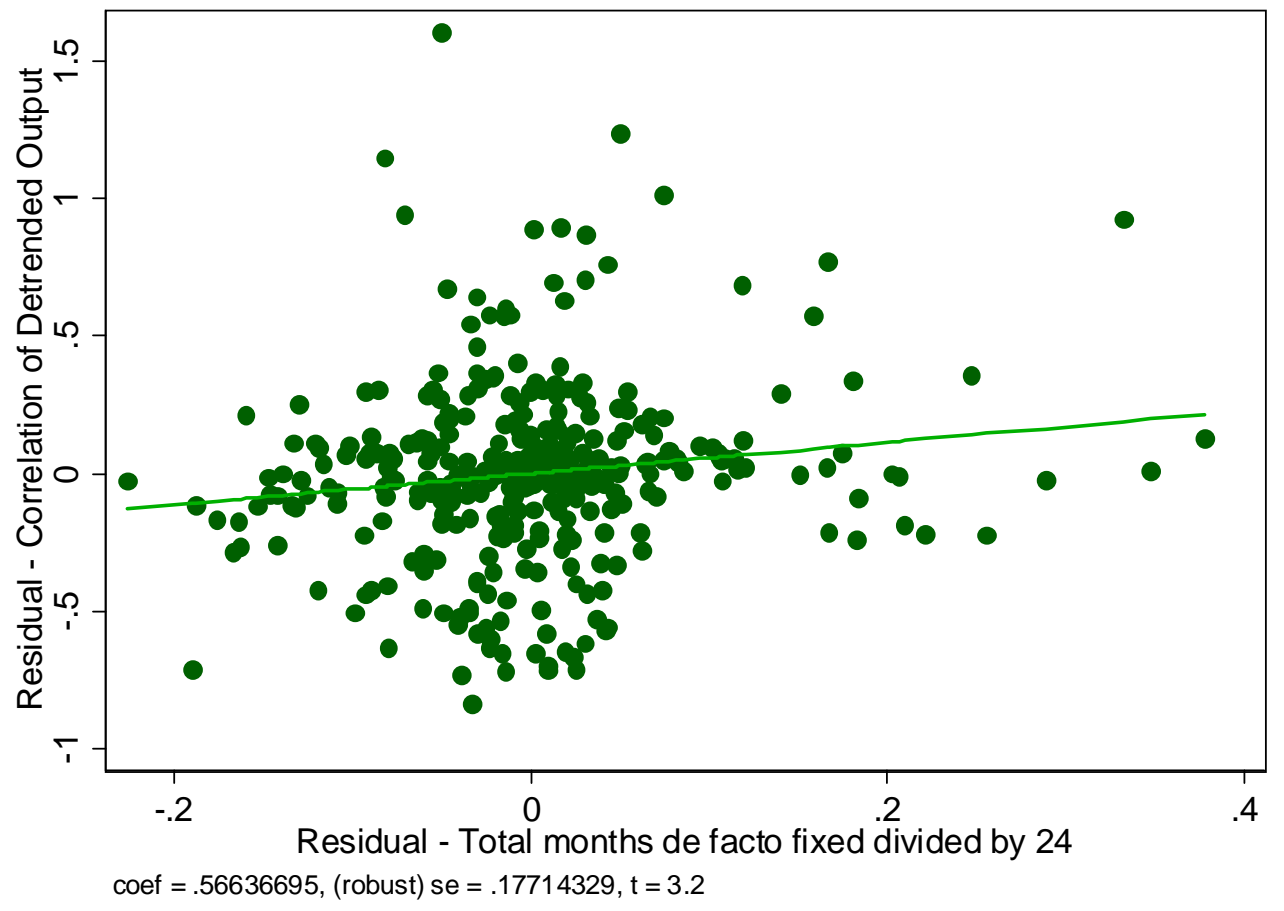


Figure 6 Predicted values of co-movement under three scenarios.

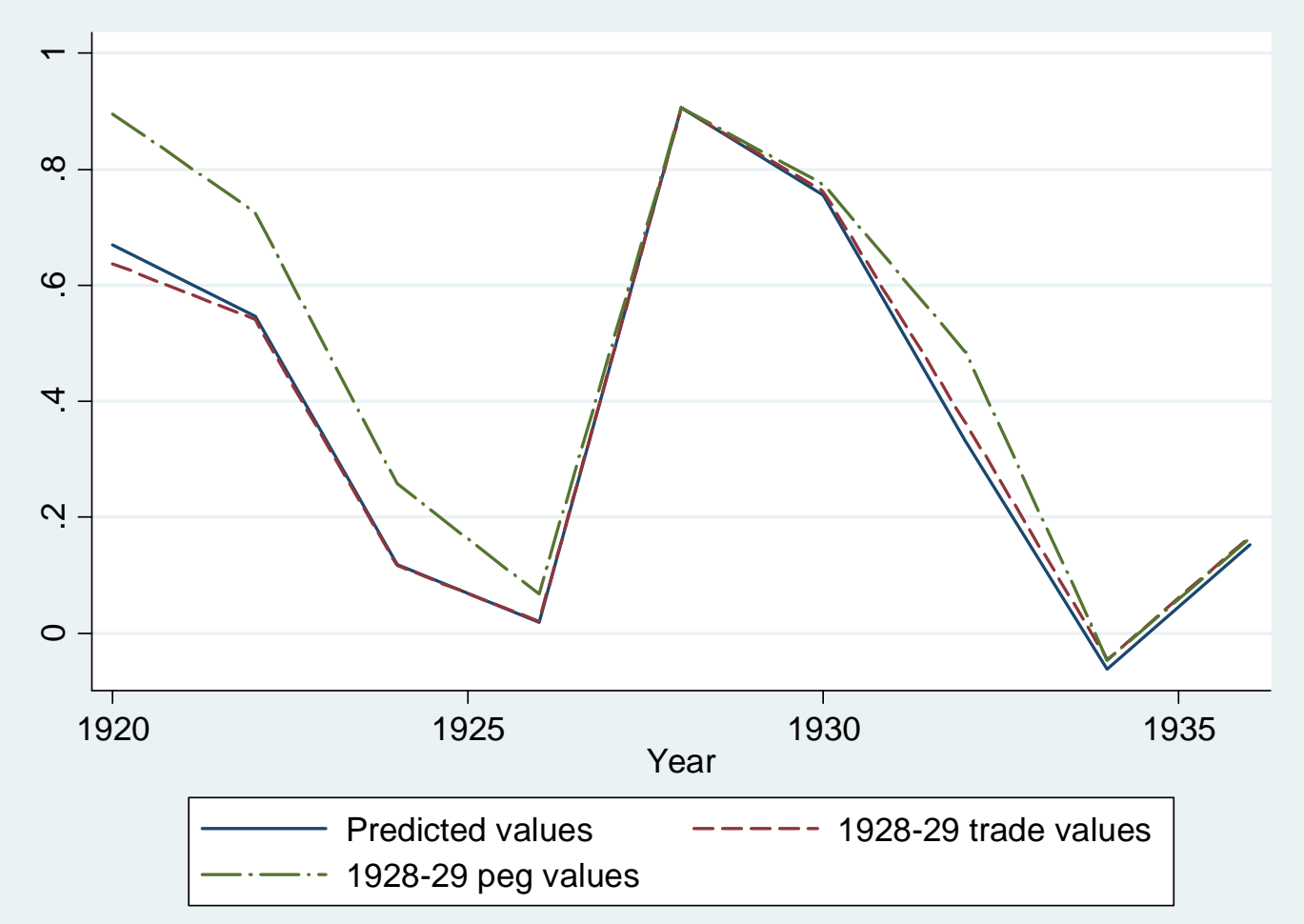

Notes: The line showing predicted values gives the actual predicted values from the model of Table 1 column 2. The line for 1928-29 peg values uses the same model but predicts using the bilateral value of the fixed exchange rate variable in 192829. The 1928-29 trade values line predicts using the trade values from 1928-29. 